\title{
Contribution of earthworms to PCB bioremediation
}

\author{
A.C. Singer ${ }^{\mathrm{a}, *}$, W. Jury ${ }^{\mathrm{a}}$, E. Luepromchai ${ }^{\mathrm{a}}$, C.-S. Yahng ${ }^{\mathrm{b}}$, D.E. Crowley ${ }^{\mathrm{a}}$ \\ ${ }^{\mathrm{a}}$ Department of Soil and Water Sciences, University of California, Riverside, CA 92521, USA \\ ${ }^{\mathrm{b}}$ Department of Microbiology, Kon-Kuk University, Seoul, South Korea
}

Received 17 April 2000; received in revised form 27 July 2000; accepted 27 September 2000

\begin{abstract}
Twenty cm deep columns containing Aroclor 1242 contaminated soil were bioaugmented with the PCB-degrading micro-organisms, Ralstonia eutrophus $\mathrm{H} 850$ and Rhodococcus sp. strain ACS, each of which were grown on sorbitan trioleate, and induced for PCB degradation by salicylic acid and carvone, respectively. Treatments consisted of soils with and without earthworms. Earthworms were utilized to enhance the dispersal of the bioaugmented PCB-degrading micro-organisms, while simultaneously improving soil aeration, increasing soil carbon and nitrogen content, and modifying the soil microbial community. Bioaugmented soils containing the earthworm Pheretima hawayana achieved 55\% removal of total soil PCB as compared to only $39 \%$ in identically treated soils without earthworms. Earthworm-treated soils achieved upwards of 65\% PCB degradation at subsurface depths, as compared to 44\% in soils without earthworms and prior reports of only $10 \%$ degradation in soils treated without manual mixing of the inoculum into the soil (McDermott et al., 1989. Two strategies for PCB soil remediation: biodegradation and surfactant extraction. Environmental Progress 8, 46-51). A methane diffusion study demonstrated that soils containing earthworms attained greater gas diffusion rates. Breakthrough of the methane tracer through the 20 -cm column was detected after only $10 \mathrm{~min}$ in soils with earthworms, while $340 \mathrm{~min}$ was required before breakthrough in soils without earthworms. Using a gas diffusion model, the experimental diffusion coefficients were calculated to be $4.45 \times 10^{-3}$ and $5.0 \times 10^{-4} \mathrm{~cm}^{2} \mathrm{~s}{ }^{-1}$, respectively. The higher diffusion rate of oxygen into the soil profile provided greater concentrations of the necessary terminal electron acceptor for aerobic PCB degradation. Methane depletion was observed only in soils with earthworms and was attributed to microbial communities unique to the earthworm treated soils. The potential contribution of these communities toward PCB degradation is discussed. (C) 2001 Elsevier Science Ltd. All rights reserved.
\end{abstract}

Keywords: Earthworm; PCB; Bioremediation; Bioaugmentation; Aeration; Pheretima hawayana

\section{Introduction}

Bioaugmentation of soil with xenobiotic-degrading micro-organisms is generally hindered by the poor transport and dispersal of soil inoculants (Elsas and Heijnen, 1990), and has been criticized as an ineffective strategy for treating contaminated soils (Goldstein et al., 1985). In situ bioremediation is also limited by the supply of suitable electron acceptors (Harding, 1997; Margesin et al., 2000). Whereas anaerobic conditions can lead to dechlorination of halogenated xenobiotics, such as PCB's (Wiegel and Wu, 2000), their mineralization is exclusively aerobic (Furukawa, 1982; Robinson and Lenn, 1994). Consequently, in oxygenlimited sites, such as the soil subsurface, PCB mineralization can be limited without manual mixing of the contaminated soil (McDermott et al., 1989) or the introduction of

\footnotetext{
* Corresponding author. Tel.: +1-909-787-3785; fax: +1-909-787-3993.

E-mail address: asinger@mail.ucr.edu (A.C. Singer).
}

oxygen from forced air, pure oxygen or hydrogen peroxide (Alexander, 1999; Harkness et al., 1993). In nature, the movement of soil animals and earthworms can enhance the transport and distribution of bacteria. Earthworms have been shown to improve the dispersal of soil inoculants through bioturbation (Daane et al., 1997; Doube et al., 1994; Hampson and Coombes, 1989; Hutchinson and Kamel, 1956; Singer et al., 1999; Stephens et al., 1994; Thorpe et al., 1996), and transport of the microbial inoculant into the burrows via bypass flow (Bouma et al., 1982; Edwards et al., 1992; Ehlers, 1975; Farenhorst et al., 2000; Lee, 1985; Madsen and Alexander, 1982; Pivetz and Steenhuis, 1995). Earthworm activity and burrowing also has been shown to increase soil aeration (Kretzschmar, 1978; Kretzschmar, 1987; Lee, 1985; Schack-Kirchner and Hildebrand, 1998). Through their mucilaginous secretions, earthworms 'prime' the soil, thereby increasing microbial activity and mineral nutrient availability (Wolters, 2000). Despite the abundance of evidence suggesting earthworms could contribute 
significantly to improving in situ xenobiotic remediation through mixing, aeration, and improved soil fertility, there has been surprisingly little research on their use in a bioremediation strategy.

In prior research, we developed a soil PCB bioremediation treatment that employed repeated augmentation of PCB-degrading bacteria to soil with a surfactant, which is used as a growth substrate by the inoculum and as a detergent to help solubilize PCBs. During inoculum production, the bacteria were induced to cometabolize PCBs by the addition of the monoterpene carvone, or with salicylic acid (Singer et al., 2000). Utilization of these two inducing substrates represents a major improvement over the use of biphenyl as an inducing substrate, as this latter compound is both highly insoluble and environmentally hazardous. In this manner, significant PCB degradation was achieved in soil microcosms, with greater than 55\% removal of Aroclor 1242 after 18 weeks in treated soils. Despite laboratory successes in bioremediating PCB from soil (Barriault and Sylvestre, 1993; Brunner et al., 1985; Gilbert and Crowley, 1998; Haluska et al., 1995; Lajoie et al., 1994; Lajoie et al., 1993; McDermott et al., 1989; Viney and Bewley, 1990), a major limitation continues to be the requirement for manual mixing of the soil, which is impractical at the field scale. The best documented example of this problem is a study by McDermott et al. (1989), who showed that bioaugmentation with Burkholderia cepacia LB400 (previously Pseudomonas putida LB400) grown on biphenyl and inoculated into soil three times weekly resulted in $50 \%$ degradation of Aroclor 1242 in the top centimeter of an unmixed soil, but less than $10 \%$ at lower soil depths.

In an effort to overcome this problem, the study reported here examined the efficacy of the earthworm Pheretima hawayana, for introducing PCB-degrading bacteria into soil. An integrated approach was used, in which two bacterial species, Rhodococcus sp. ACS and Ralstonia eutrophus H850, were grown on the surfactant sorbitan trioleate, along with carvone and salicylic acid, respectively, as substrates for induction of PCB degradation. In this integrated bioremediation strategy, the anecic earthworms (Bouche, 1975) migrate continuously between the surface and lower soil profile and deposit contaminated soil onto the surface, which is repeatedly inoculated with PCB-degrading bacteria. The constant mixing of the inoculum and soil within the earthworm is also thought to help distribute the bacteria over the soil particle surfaces and thereby increase their proximity to sorbed PCBs. Since aerobic degradation of PCBs by these two micro-organisms is dependent on oxygen availability, it was also of interest to quantify the effect of earthworms on soil gas diffusion. A non-conservative tracer, methane, was chosen to evaluate gas diffusion through the soil profile using a gas diffusion transport model. Depletion of the methane tracer provided evidence for the presence of ammonia-oxidizing microbial populations within earthworm treated soils, and may account for some of the observed PCB removal.

\section{Materials and methods}

\subsection{Chemicals}

L-Carvone was obtained from Aldrich Chemical Co. (Milwaukee, WI, USA). Aroclor 1242 was purchased from AccuStandard, Inc. (New Haven, CT, USA). Triton X-100 and sorbitan trioleate (ST) were purchased from Sigma (Saint Louis, MO, USA). Salicylic acid (SA) was purchased from Fisher Scientific, Inc. (Pittsburgh, PA, USA). All solvents were Optima grade.

\subsection{Bacterial culture}

The PCB degrading bacteria $R$. eutrophus $\mathrm{H} 850$ (Bedard et al., 1983) and Rhodococcus sp. ACS were maintained on biphenyl as the sole carbon source as previously described (Gilbert and Crowley, 1997). Rhodococcus sp. ACS was isolated by Andrew Singer from a PCB-contaminated soil obtained from a site in Staten Island, New York in 1997. The bacterium is similar in morphology to Arthrobacter sp. strain B1B (Kohler et al., 1988) and shares Arthrobacter sp. strain B1B's ability to cometabolize PCB when grown in the presence of carvone, as well as other terpenes, such as citral and cineole.

\subsection{Soil microcosm preparation}

Twenty-four $30 \mathrm{~cm}$ long, $5.08 \mathrm{~cm}$ ( 2 in) diameter polyvinyl chloride (PVC) soil columns were prepared by affixing a piece of plastic, open-weave fabric to one end of the column using duct tape. Approximately $75 \mathrm{~g}$ of pebbles were added to the bottom of each tube. A layer of glass wool was added to completely cover the upper surface of the pebbles and minimize soil loss. Each tube was filled with $0.6 \mathrm{~kg}$ of PCB contaminated soil. Once filled, the columns contained $20 \mathrm{~cm}$ of soil-filled space, and $5 \mathrm{~cm}$ on both ends of air-filled space. The final bulk density of the soil was $1.48 \mathrm{~g} \mathrm{~cm}^{-3}$, with a total porosity of $0.44 \mathrm{~cm}^{3} \mathrm{~cm}^{-3}$ and an air content of $0.33 \mathrm{~cm}^{3} \mathrm{~cm}^{-3}$. Polyethylene foam plugs (PUFs) were inserted into the top of the soil columns to adsorb any volatilized PCBs and were analyzed as described below.

\subsection{Soil preparation}

Five $\mathrm{kg}$ of air dry soil (coarse loamy, mixed, thermic Haplic Durixeralf, pH 7.5, 0.21\% carbon, $0.01 \%$ nitrogen) was sieved though a $2 \mathrm{~mm}$ sieve. Five $\mathrm{g}$ of Aroclor 1242 was dissolved in $275 \mathrm{ml}$ hexane and mixed into the $5 \mathrm{~kg}$ of soil. The soil was mixed thoroughly for $0.5 \mathrm{~h}$ and allowed to sit for 5 days to allow the hexane to volatilize. The contaminated soil was thoroughly mixed into an additional $45 \mathrm{~kg}$ of uncontaminated sieved soil to make a final concentration of $100 \mathrm{mg}$ Aroclor $1242 \mathrm{~kg}^{-1}$ soil. After 4 days, $0.6 \mathrm{~kg}$ of the contaminated soil was added to each of 24 PVC columns and allowed to equilibrate for an additional 90 days in a greenhouse at the University of California, with an ambient 
temperature averaging $26^{\circ} \mathrm{C}$. One week before the beginning of the study, each column was brought to field capacity (approximately $-33 \mathrm{kPa}$ ) with the addition of $70 \mathrm{ml}$ of deionized water and $70 \mathrm{ml}$ of minimal salts media (MSM), establishing a water content of $12 \%$. The mass of each soil column was noted to assess the extent of water loss between each soil inoculation, and to determine the volume of inoculum to be added.

\subsection{Treatments}

The experiment contained columns with and without earthworms, and three soil amendment treatments. One treatment employed bioaugmentation with $R$. eutrophus H850 and Rhodococcus sp. ACS, which were added along with the spent medium. The Rhodococcus sp. ACS culture originally contained $100 \mathrm{mg} \mathrm{l}^{-1}$ carvone, and $1000 \mathrm{mg} \mathrm{l}^{-1}$ sorbitan trioleate dissolved in MSM, whereas the R. eutrophus $\mathrm{H} 850$ culture originally contained $500 \mathrm{mg} \mathrm{l}^{-1}$ salicylic acid and $1000 \mathrm{mg}^{-1}$ sorbitan trioleate dissolved in MSM. The remaining treatment received MSM only. Four replicate columns were prepared for each amendment type.

\subsection{Vermiculture}

Earthworms, $P$. hawayana (Rosa, 1891), were selected on the basis of their anecic burrowing, casting and comminution habit as well as their tolerance of relatively high soil temperatures. The earthworms were originally acquired from Valley Worm Growers (Ridgecrest, CA, USA), and were subsequently maintained in $1 \times 1 \times 0.3 \mathrm{~m}$ bins in the greenhouse with a 1:1 (v:v) mixture of local agricultural soil and Canadian sphagnum peat moss. Vermiculture bins were repeatedly amended with rolled oats as an earthworm food source. One-hundred twenty $P$. hawayana were randomly selected from the earthworm bins and incubated in uncontaminated experimental soil for $48 \mathrm{~h}$, after which they were washed with deionized water and added to the soil columns. Ten earthworms were added to each column, 1 week before the first inoculum amendment.

\subsection{Inoculum preparation}

Microbial cultures were grown in $250 \mathrm{ml}$ Erlenmeyer flasks containing $100 \mathrm{ml} \mathrm{MSM}$, and shaken on a rotary shaker at $250 \mathrm{rev} \mathrm{min}^{-1}$. After approximately $20 \mathrm{~h}$ growth, an additional $50 \mu \mathrm{l}(500 \mathrm{ppm})$ of sorbitan trioleate was added to each culture flask. Previous analysis had shown that approximately $100 \mathrm{mg} \mathrm{l}^{-1}$ of sorbitan trioleate remained after $20 \mathrm{~h}$ of growth, thereby necessitating the addition of more surfactant before inoculation of the soil columns. The additional surfactant also provided the inoculum with a temporary carbon source, and helped to maintain the surfactant concentration above the critical micelle concentration $\left(90 \mathrm{mg} \mathrm{l}^{-1}\right)$. The vials were shaken for an additional $15 \mathrm{~min}$ to allow the sorbitan trioleate to dissolve into the medium, at which time the inoculum was applied to the soil columns. Ten ml of aqueous amendment was sufficient to replenish the water loss between amendment applications. Each $10 \mathrm{ml}$ application in the case of bioaugmented treatments was comprised of approximately $10^{8}$ cells, $6 \mu \mathrm{l}$ of sorbitan trioleate, $1 \mu \mathrm{l}$ of carvone or $1-5 \mathrm{mg}$ salicylic acid. After 36 applications, the total quantity applied approximated $216 \mu \mathrm{l}$ sorbitan trioleate, $36 \mu \mathrm{l}$ carvone and $36-180 \mathrm{mg}$ salicylic acid per column. In the case of biostimulated treatments, each amendment was comprised of exactly $5 \mu \mathrm{l}$ of sorbitan trioleate, $1 \mu \mathrm{l}$ of carvone and $5 \mathrm{mg}$ salicylic acid. This constituted $180 \mu \mathrm{l}$ sorbitan trioleate, $36 \mu \mathrm{l}$ carvone and $180 \mu \mathrm{l}$ salicylic acid per column after 36 amendments. Amendments were applied twice weekly, alternating R. eutrophus $\mathrm{H} 850$ and Rhodococcus sp. ACS cultures. Amendments began 1 week after introduction of the earthworms and continued twice weekly for 18 weeks. In earthworm treatments, approximately $1 \mathrm{~g}$ of rolled oats were added to the soil surface simultaneously with the inoculum amendment. Oatmeal was added to the surface of the columns without earthworms at the beginning of the 18-week period; additional applications were not required.

\subsection{Soil sampling}

Soil sampling was conducted at week 19 (1 week after the last amendment). The soil was removed from the PVC pipe using a $5-\mathrm{cm}$ disc and long metal rod to push the core out from one end. Twenty-two g soil samples were removed from each of the following three depths: 0-2, 2-6 and $6-20 \mathrm{~cm}$, and placed in $40 \mathrm{ml}$ glass vials for PCB extraction. Two randomly chosen columns from each amendment type were selected for moisture content analysis. Twentyfive $\mathrm{g}$ soil samples from each of two depths, 2-6 and 6$20 \mathrm{~cm}$, were placed into $20 \mathrm{ml}$ glass vials and weighed before and after oven drying at $105^{\circ} \mathrm{C}$ for $24 \mathrm{~h}$ to determine water content (Rowell, 1994).

Carbon and nitrogen analyses were performed on the same soil samples used for water content analyses. The soil was ground into a powder using a mortar grinder (Ratsch Type RM-0, Gmblt \& Co., Germany), at which time 40-mg samples were prepared for total carbon and nitrogen analyses as per manufacturer instructions. Samples were analyzed on a Carlo Erba Nitrogen Analyzer Model 1500-R/AS 200 (Carlo Erba Instruments, Milan, Italy).

The population sizes of biphenyl-utilizing microorganisms were determined using $0.5 \mathrm{~g}$ soil samples taken from two randomly selected columns from each treatment at each of three depths: $0-2,2-6$ and 6$20 \mathrm{~cm}$. These $0.5 \mathrm{~g}$ replicate samples from each depth were mixed and suspended into $9 \mathrm{ml} \mathrm{MSM}$ for determination of colony forming units (cfu) of biphenyl utilizers. Serial dilutions were spread plated onto duplicate $1.5 \%$ noble-agar-MSM Petri plates, which were placed in an evacuation chamber containing biphenyl vapors as a sole 
carbon source. Biphenyl-utilizer colonies were counted after a 2-week incubation. Rhodococcus sp. ACS colonies were identified by their characteristic pink color and later confirmed using fatty acid methyl ester (FAME) profiles (MIDI, Inc., Newark, Delaware, USA). Isolation of $R$. eutrophus H850 was not conducted due to the lack of a suitable marker for identification.

\subsection{PCB extraction and quantification}

Four $\mathrm{ml}$ of $1 \%$ Triton X-100, $1 \mathrm{ml}$ of acetone and $10 \mathrm{ml}$ of hexane were added to $22 \mathrm{~g}$ soil samples in 40-ml glass vials. The vials were sealed with Teflon tape and placed on a horizontal shaker for $24 \mathrm{~h}$, followed by centrifuging for $15 \mathrm{~min}$ at $500 \mathrm{rev} \mathrm{min}^{-1}$. The vials were then frozen at $-20^{\circ} \mathrm{C}$ to solidify the lower aqueous layer, and a $5-\mathrm{ml}$ aliquot of the hexane fraction was transferred to a $12-\mathrm{ml}$ glass vial containing 2-3 g of anhydrous sodium sulfate. A 1-ml aliquot of the hexane fraction was transferred to a gas chromatography (GC) vial for analysis. GC analyses were performed with a Hewlett-Packard 5890 GC equipped with an FID (Hewlett-Packard Co., Palo Alto, CA, USA). The column was a 60-m HP-5ms [J\&W Scientific, Folsom, CA, USA (5\% phenyl)-methylpolysiloxane phase; ID, $0.25 \mathrm{~mm}$; film thickness, $0.25 \mathrm{~mm}$ ]. The injector and detector temperatures were $250^{\circ} \mathrm{C}$ and $300^{\circ} \mathrm{C}$, respectively. The carrier gas was hydrogen $\left(30 \mathrm{ml} \mathrm{min}^{-1}\right)$. Detector gases were $30 \mathrm{ml}$ nitrogen $\min ^{-1}$ and $340 \mathrm{ml}$ zero air $\min ^{-1}$. PCBs were analyzed with the following temperature program: initial temperature, $160^{\circ} \mathrm{C}$; hold for $1 \mathrm{~min}$; ramp at $1.4^{\circ} \mathrm{C} \mathrm{min}^{-1}$ until $300^{\circ} \mathrm{C}$.

Each treatment was analyzed for recovery of PCB and further analyzed by dividing into five congener class groups (mono-, di-, tri-, tetra-, and penta-chlorobiphenyls). PCB recovery was evaluated by comparing recovered PCB to a standard curve of Aroclor 1242. Congener groupings were based on analysis of relative retention times (Schulz et al., 1989). The recovery of each congener group was evaluated as a percent of the total PCB recovered from each depth. Total PCB degradation by treatment was calculated by summing the product of the PCB degraded from each depth by the percent that that depth contributed to the sum of soil in the column. More specifically, the $0-2 \mathrm{~cm}$ depth contributed $10 \%$ to the total volume of soil in the column, the $2-6 \mathrm{~cm}$ depth contributed $20 \%$, and the $6-20 \mathrm{~cm}$ depth contributed $70 \%$.

Earthworm tissue analyses were conducted by collection of earthworms from the soil columns, which were then maintained without soil for 3 days in a glass jar to allow the earthworms to void their guts prior to extraction. Earthworms were washed on a wire screen under a stream of deionized water. Ten $\mathrm{g}$ of earthworms (approximately $0.55 \mathrm{~g} \mathrm{worm}^{-1}$ ) were measured into a mortar and immersed in liquid nitrogen. The earthworms were ground with a pestle and transferred into 40-ml Teflon-lined glass vials where they were further pulverized with a tissue grinder.
Four $\mathrm{ml}$ of $1 \%$ Triton $\mathrm{X}-100$ solution, $10 \mathrm{ml}$ hexane and $1 \mathrm{ml}$ acetone were added to the vials, which were then placed on a horizontal shaker for $24 \mathrm{~h}$. The vials were centrifuged for $15 \mathrm{~min}$ at $500 \mathrm{rev} \mathrm{min}^{-1}$, after which they were held at $-20^{\circ} \mathrm{C}$ for $24 \mathrm{~h}$ to separate the organic phase from the aqueous layer. A $5 \mathrm{ml}$-aliquot of the hexane layer was transferred to an activated $6 \mathrm{ml}$ Supelclean LC-Florisil SPE tube (Supelco Inc., Bellefonte, PA, USA). The filtered hexane fraction was collected and analyzed by GC as described above.

Gas phase loss of PCB, a major route of lower chlorinated PCB congener loss in the environment, was evaluated through the extraction and analysis of PCB in the PUF plugs. The PUF plugs were stored at $-20^{\circ} \mathrm{C}$ until extraction. A $1 \mathrm{~g}$ subsample of the PUF plug ( $3.30 \mathrm{~g}$ per plug) was removed and extracted in a $40-\mathrm{ml}$ vial using $20 \mathrm{ml}$ of double-deionized water, and $10 \mathrm{ml}$ of hexane. The hexane fraction was analyzed by GC as described above.

\subsection{Gas diffusion analysis}

One soil column from each treatment was subjected to a methane diffusion assay that enabled quantification of the contribution of earthworms to increased gas diffusion in the soil columns. An increase in the methane diffusion coefficient can be used to imply increased oxygen diffusion, which can potentially enhance aerobic PCB degradation and microbial activity. Methane was chosen as the tracer gas because it has a similar water solubility as oxygen and can be quantified easily by gas chromatography using a flame ionizing detector. Being a semi-conservative tracer, depletion of methane can also provide valuable information on the functional capability of the indigenous microbial population.

A representative soil column from each treatment was capped tightly with a rubber pipe cap fitted with a Teflon septum. A $2.5 \mathrm{cc}$ pulse of methane was injected into the bottom of the sealed soil column through the septum using a $3 \mathrm{cc}$ syringe, while simultaneously drawing out $2.5 \mathrm{cc}$ of air to ensure there was no net pressure change in the column. The top and bottom air reservoirs in the soil column (designated $\mathrm{H}$ in Fig. 1) were sampled 10 times within $340 \mathrm{~min}$. At each sampling time, a $10 \mu \mathrm{l}$ gas sample was drawn from both air reservoirs and immediately analyzed by GC. A gas diffusion coefficient was calculated based on of the best fit of a gas diffusion transport model to the methane concentration in the inlet and outlet reservoirs over time. Data from the control column was fitted by assuming zero degradation of methane in the soil during transport, however a substantial amount of methane removal was observed in the earthworm-treated column over time. For this treatment, both a diffusion coefficient and a firstorder degradation coefficient were simultaneously fitted to the data. 


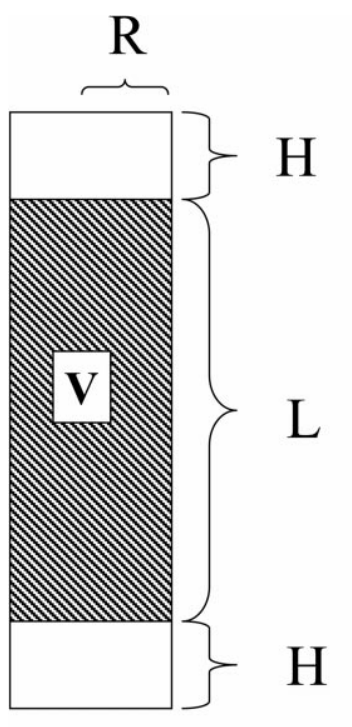

$\mathrm{H}=5 \mathrm{~cm}$ (air reservoir)

$\mathrm{L}=20 \mathrm{~cm}$ (soil column)

$\mathrm{R}=2.54 \mathrm{~cm}$ (column radius)

$\mathrm{V}=405 \mathrm{~cm}^{3}$ (soil volume)

$\rho=1.48 \mathrm{~g} \mathrm{~cm}^{-3}$ (soil bulk density)

$\theta=0.11$ (soil water content)

Fig. 1. Soil column schematic and parameters.

\subsection{Methane diffusion model}

Fig. 1 shows a schematic of the column dimensions and boundary conditions. The gas is assumed to move through the soil by molecular diffusion. The concentration profile in the soil may be calculated by the diffusion equation

$a \frac{\partial C}{\partial t}=D_{\mathrm{g}}^{\mathrm{s}} \frac{\partial^{2} C}{\partial x^{2}}-\mu a C$

(Carslaw and Jaeger, 1959) where a is soil volumetric air content (vol air/vol. soil), $C$ is soil gas concentration $\left(\mathrm{g} / \mathrm{m}^{3}\right)$, $x(\mathrm{~m})$ is distance along the column, $D\left(\mathrm{~cm}^{2} \mathrm{~s}^{-1}\right)$ is the diffusion coefficient of the gas in soil, $\mu\left(\mathrm{s}^{-1}\right)$ is the first order degradation coefficient, and $t(\mathrm{~s})$ is time.

\subsection{Boundary and initial conditions}

To solve Eq. (1) it is necessary to specify two boundary conditions. Since the diffusion coefficient of gas in air is quite large, it is reasonable to assume that the gas in the air chambers is well mixed. Thus, according to Carslaw and Jaeger (1959), the appropriate boundary conditions are:

$H \frac{\partial C}{\partial t}=D \frac{\partial C}{\partial x} \quad$ at $\quad x=0 ; C(0,0)=C o$

$H \frac{\partial C}{\partial t}=-D \frac{\partial C}{\partial x} \quad$ at $\quad x=L ; C(L, 0)=0$ where $C o$ is the initial concentration of gas injected into the inlet reservoir, $L$ is the length of the soil column, and $H$ is the length of the inlet and outlet reservoirs.

Eqs. (1)-(3) are solved by Laplace transformation (Carslaw and Jaeger, 1959) for the case of zero initial gas in the soil, and an instantaneous injection of gas into the entry chamber. The solution for the gas concentration in transform space is (Carslaw and Jaeger, 1959):

$$
\begin{aligned}
& \bar{C}(x ; s)= \\
& \quad H C_{0} \frac{[(D q-s H) \exp [-q(L-x)]+(D q+s H) \exp [q(L-x)]}{(D q+s H)^{2} \exp [q L]-(D q-s H)^{2} \exp [-q L]}
\end{aligned}
$$

where

$q=\sqrt{\frac{a(s+\mu)}{D}}$

and $C(x ; s)$ is the Laplace transform of the gas concentration, given by

$\bar{C}(x ; s)=\int_{0}^{\infty} \exp (-s t) C(x, t) \mathrm{d} t$

Eq. (4) may be inverted numerically using the routine given in Jury and Roth (1990) to yield values of $C(x, t)$.

In our experiment, the concentration at the inlet and outlet ends of the column were measured over time. These values were fitted to the model predictions [Eq. (4)] by varying $D$ and $\mu$ until the sum of squares of the differences between the model and data were minimized.

\section{Results}

\subsection{PCB recovery}

PCB removal was greater in soils with earthworms as compared to all treatments without earthworms (Table 1). In addition, the earthworm-treated soils had a more uniform distribution of residual PCBs at all depths in bioaugmented and biostimulated treatments as compared to soils without earthworms. Bioaugmentation of PCB-degrading bacteria to the earthworm-treated soils resulted in an average removal of $55 \%$, as compared to only $39 \%$ removal in bioaugmented soils without earthworms $(P<0.05)$. Bioaugmented earthworm-treated soil achieved PCB removals of $65 \%$ within the $2-6 \mathrm{~cm}$ depth, while only $26 \%$ PCB removal was achieved in soils without earthworms at the same depth $(P<0.05)$. Biostimulated earthworm-treated soil also resulted in a uniform pattern of PCB removal by depth of 44 and $45 \%$ within the $0-2$, and $2-6 \mathrm{~cm}$ depths, respectively. In comparison, soils without earthworms resulted in 60 and 27\% PCB removal in the same $0-2$, and $2-$ $6 \mathrm{~cm}$ depths, respectively.

Soils without earthworms had the greatest PCB removal in the MSM-amended soils, achieving 58, 44, and $43 \%$ at 
Table 1

PCB removal in treated soils after 18 weeks in the presence and absence of earthworms (BA, bioaugmented soil, containing both PCB-degrading bacteria with carvone, salicylic acid and sorbitan trioleate in a minimal salts medium; BS, biostimulated soil, containing only carvone, salicylic acid and sorbitan trioleate in a minimal salts medium; MSM, minimal salts medium)

\begin{tabular}{|c|c|c|c|c|c|c|}
\hline \multirow[t]{3}{*}{ Soil depth } & \multicolumn{6}{|c|}{ Treatment (\% PCB removed $\mathrm{g}^{-1}$ soil) } \\
\hline & \multicolumn{3}{|c|}{ Earthworm } & \multicolumn{3}{|c|}{ No Earthworm } \\
\hline & BA & BS & MSM & BA & BS & MSM \\
\hline $0-2 \mathrm{~cm}$ & $66^{\mathrm{aA}}$ & $44^{\mathrm{bA}}$ & $67^{\mathrm{aA}}$ & $52^{\mathrm{abB}}$ & $60^{\mathrm{abB}}$ & $58^{\mathrm{aA}}$ \\
\hline $2-6 \mathrm{~cm}$ & $65^{\mathrm{aA}}$ & $45^{\mathrm{abA}}$ & $39^{\mathrm{bB}}$ & $26^{\mathrm{bA}}$ & $27^{\mathrm{bA}}$ & $44^{\mathrm{abA}}$ \\
\hline $6-20 \mathrm{~cm}$ & $50^{\mathrm{aA}}$ & $50^{\mathrm{aA}}$ & $53^{\mathrm{aA}}$ & $41^{\mathrm{aAB}}$ & $38^{\mathrm{aAB}}$ & $43^{\mathrm{aA}}$ \\
\hline Total $^{\mathrm{a}}$ & $55^{\mathrm{a}}$ & $48^{\mathrm{a}}$ & $52^{\mathrm{a}}$ & $39^{\mathrm{b}}$ & $38^{\mathrm{b}}$ & $45^{\mathrm{b}}$ \\
\hline
\end{tabular}

${ }^{a}$ Soil PCB removal values at the same depth are significantly different $(P<0.05)$ if marked with different lower case letters (two factor ANOVA with repeated measure using Student-Newman-Keuls). PCB removal values within the same treatment are significantly different $(P<0.05)$ if denoted with different uppercase letters (two factor ANOVA using StudentNewman-Keuls).The total PCB removal from treatments were weighted to account for differences in the volume of soil at each depth, as discussed in the text. Statistically significant values of the total PCB removal is denoted with different lowercase letters (one-way ANOVA using LSD). All analyses were conducted using SAS (Cary, NC).

the $0-2,2-6$ and $6-20 \mathrm{~cm}$ depths, respectively, averaging $45 \%$ PCB removal per column. The average PCB removal from the MSM-treated soil without earthworms was $14 \%$ lower than the corresponding treatment with earthworms, which resulted in 52\% PCB removal $(P<0.05)$. Earthworm-treated soils amended with MSM resulted in 67 and $39 \%$ PCB removal, from the $0-2$ and $2-6 \mathrm{~cm}$ depths, respectively.

An Aroclor 1242 standard was used to compare recovered PCBs by congener class at each depth (Table 2). The Aroclor 1242 standard contains 13\% di-, 45\% tri-, 31\% tetra-, and 10\% penta-chlorobiphenyl (Erickson, 1997), with the remaining $1 \%$ as monochlorobiphenyls, of which none were detected in any soil samples. All treatments showed a decline in the percentage of di- and tri-chlorobiphenyl recovered, with a corresponding increase in tetrachlorobiphenyl. A one- to two-fold increase in pentachlorobiphenyl was found in all treatments at all depths as compared to the Aroclor 1242 standard.

Extraction of $10 \mathrm{~g}$ of earthworms (wet weight) for PCB content revealed an average of $13 \pm 5 \mu \mathrm{g} \mathrm{PCB} \mathrm{g}^{-1}$ earthworm or $7.15 \mu \mathrm{g}$ PCB earthworm ${ }^{-1}$. Analysis of PCB recovered from the earthworm bodies revealed modest accumulations of tetra- and penta-chlorobiphenyl congeners, with relatively lower proportions of di- and trichlorobiphenyl as compared to the Aroclor 1242 standard (Table 2). The earthworm tissue averaged $44 \pm 17 \%$ tetrachlorobiphenyl, $41 \%$ higher than the Aroclor 1242 standard. The pentachlorobiphenyl congeners recovered from the earthworm tissues measured $30 \pm 12 \%, 300 \%$ more than the percentage found in an Aroclor 1242 standard, and at the high end of that found in all soils at all depths. Trichlorobiphenyl constituted $13 \pm 5 \%$ of the PCB recovered from the earthworm tissue, while $4 \pm 1 \%$ was dichlorobiphenyl, representing a decrease of 76 and $70 \%$, respectively, as compared to an Aroclor 1242 standard. No significant trends could be found in the recovery of PCB from the PUF plugs between soils with or without earthworms nor between treatments. Approximately $31 \pm 8 \mu \mathrm{g}$ PCB plug $^{-1}$ was recovered from each column after 18 weeks.

\subsection{Soil carbon and nitrogen analysis}

Soil samples from the $2-6$, and $6-20 \mathrm{~cm}$ depths were analyzed for carbon and nitrogen content to provide evidence of vertical redistribution of the soil by the earthworms (Table 3 ). The $0-2 \mathrm{~cm}$ depth was not analyzed for carbon and nitrogen because this zone received a direct application of rolled oats. Between 3.9 and 30.1 times more carbon was recovered from the $2-6 \mathrm{~cm}$ depth in earthworm-treated soil than soils without earthworms. Soils with earthworms from the $6-20 \mathrm{~cm}$ depth contained between

Table 2

Percent congener recovery from soil by sampling depths [comparisons of percent congener recoveries within a homolog class between earthworm and no earthworm treatments are significantly different $(P<0.05)$ if marked with different lowercase letters (one way ANOVA using Student-Newman-Keuls). Comparisons of percent congener recoveries within the same row are significantly different $(P<0.05)$ if marked with different uppercase letters (one way ANOVA using Student-Newman-Keuls]

\begin{tabular}{|c|c|c|c|c|c|c|c|c|c|}
\hline & \multicolumn{3}{|c|}{$0-2 \mathrm{~cm}$} & \multicolumn{3}{|c|}{$2-6 \mathrm{~cm}$} & \multicolumn{3}{|c|}{$6-20 \mathrm{~cm}$} \\
\hline & BA & BS & MSM & $\mathrm{BA}$ & BS & MSM & $\mathrm{BA}$ & BS & MSM \\
\hline \multicolumn{10}{|l|}{ No earthworm } \\
\hline Dichlorobiphenyl & $7^{\mathrm{aB}}$ & $6^{\mathrm{aA}}$ & $5^{\mathrm{aC}}$ & $6^{\mathrm{aA}}$ & $6^{\mathrm{aA}}$ & $6^{\mathrm{aA}}$ & $6^{\mathrm{aA}}$ & $6^{\mathrm{aA}}$ & $6^{\mathrm{aA}}$ \\
\hline Trichlorobiphenyl & $13^{\mathrm{aB}}$ & $17^{\mathrm{aB}}$ & $25^{\mathrm{aAB}}$ & $22^{\mathrm{aA}}$ & $25^{\mathrm{aA}}$ & $23^{\mathrm{aAB}}$ & $22^{\mathrm{aAB}}$ & $25^{\mathrm{aA}}$ & $23^{\mathrm{aAB}}$ \\
\hline Tetrachlorobiphenyl & $38^{\mathrm{aBC}}$ & $41^{\mathrm{aC}}$ & $52^{\mathrm{aBC}}$ & $49^{\mathrm{aA}}$ & $48^{\mathrm{aA}}$ & $47^{\mathrm{aABC}}$ & $48^{\mathrm{aABC}}$ & $48^{\mathrm{aAB}}$ & $51^{\mathrm{aAB}}$ \\
\hline Pentachlorobiphenyl & $41^{\mathrm{aA}}$ & $36^{\mathrm{aA}}$ & $17^{\mathrm{aA}}$ & $24^{\mathrm{aA}}$ & $21^{\mathrm{aA}}$ & $25^{\mathrm{aA}}$ & $24^{\mathrm{aA}}$ & $22^{\mathrm{aA}}$ & $20^{\mathrm{aA}}$ \\
\hline \multicolumn{10}{|l|}{ Earthworm } \\
\hline Dichlorobiphenyl & $6^{\mathrm{aA}}$ & $3^{\mathrm{aA}}$ & $6^{\mathrm{aA}}$ & $6^{\mathrm{aA}}$ & $3^{\mathrm{aA}}$ & $5^{\mathrm{aA}}$ & $5^{\mathrm{aA}}$ & $5^{\mathrm{aA}}$ & $6^{\mathrm{aA}}$ \\
\hline Trichlorobiphenyl & $27^{\mathrm{aBC}}$ & $13^{\mathrm{aBC}}$ & $28^{\mathrm{aBC}}$ & $25^{\mathrm{aBC}}$ & $14^{\mathrm{aC}}$ & $26^{\mathrm{aA}}$ & $28^{\mathrm{aAB}}$ & $19^{\mathrm{bABC}}$ & $24^{\mathrm{aABC}}$ \\
\hline Tetrachlorobiphenyl & $35^{\mathrm{aB}}$ & $60^{\mathrm{bA}}$ & $40^{\mathrm{aB}}$ & $40^{\mathrm{bB}}$ & $54^{\mathrm{aAB}}$ & $51^{\mathrm{aAB}}$ & $43^{\mathrm{aAB}}$ & $47^{\mathrm{aAB}}$ & $49^{\mathrm{aAB}}$ \\
\hline Pentachlorobiphenyl & $32^{\mathrm{aA}}$ & $23^{\mathrm{aA}}$ & $27^{\mathrm{aA}}$ & $29^{\mathrm{aA}}$ & $29^{\mathrm{aA}}$ & $19^{\mathrm{aA}}$ & $25^{\mathrm{aA}}$ & $29^{\mathrm{aA}}$ & $21^{\mathrm{aA}}$ \\
\hline
\end{tabular}


Table 3

Soil carbon and nitrogen content in bioaugmented and biostimulated soils after 18 weeks in the presence and absence of earthworms

\begin{tabular}{|c|c|c|c|c|c|c|}
\hline \multirow[t]{2}{*}{ Treatment } & \multicolumn{2}{|c|}{ BA $\left(10^{-2} \mathrm{mg} \mathrm{g}^{-1}\right.$ soil $)$} & \multicolumn{2}{|c|}{ BS $\left(10^{-2} \mathrm{mg} \mathrm{g}^{-1}\right.$ soil $)$} & \multicolumn{2}{|c|}{$\operatorname{MSM}\left(10^{-2} \mathrm{mg} \mathrm{g}^{-1}\right.$ soil $)$} \\
\hline & $2-6 \mathrm{~cm}$ & $6-20 \mathrm{~cm}$ & $2-6 \mathrm{~cm}$ & $6-20 \mathrm{~cm}$ & $2-6 \mathrm{~cm}$ & $6-20 \mathrm{~cm}$ \\
\hline \multicolumn{7}{|l|}{ No earthworm soil } \\
\hline Soil carbon & 64.3 & 68.9 & 20.1 & 28.3 & 11.8 & 22.0 \\
\hline Soil nitrogen & 9.2 & $<0.1$ & $<0.1$ & $<0.1$ & 12.1 & 2.16 \\
\hline \multicolumn{7}{|l|}{ Earthworm soil } \\
\hline Soil carbon & 248.1 & 84.8 & 606.9 & 78.4 & 85.9 & 96.2 \\
\hline Soil nitrogen & 35.8 & 1.1 & 119.3 & 19.0 & 27.6 & 18.3 \\
\hline Earthworm/no earthworm ${ }^{a}$ & 3.9 & 1.2 & 30.1 & 2.8 & 7.2 & 4.4 \\
\hline
\end{tabular}

${ }^{\text {a }}$ Ratio of carbon recovered from earthworm-influenced soil to no earthworm soil. A similar ratio was not calculated for nitrogen since the concentration of this element was below the detection limit.

Table 4

Population sizes of biphenyl-degrading bacteria in treated soils

\begin{tabular}{|c|c|c|c|c|c|c|c|c|c|}
\hline \multirow[t]{2}{*}{ Treatment } & \multicolumn{3}{|c|}{ Bioaugmented $\left(10^{8} \mathrm{cfu} \mathrm{g}^{-1}\right.$ soil $)$} & \multicolumn{3}{|c|}{ Biostimulated $\left(10^{8} \mathrm{cfu} \mathrm{g}^{-1}\right.$ soil $)$} & \multicolumn{3}{|c|}{$\operatorname{MSM}\left(10^{8} \mathrm{cfu} \mathrm{g}^{-1}\right.$ soil $)$} \\
\hline & $0-2^{\mathrm{a}}$ & $2-6$ & $6-20$ & $0-2$ & $2-6$ & $6-20$ & $0-2$ & $2-6$ & $6-20$ \\
\hline No earthworm soil & 12 & 3.3 & 0.39 & 12 & 3.6 & 1.2 & 0.58 & 0.38 & 0.27 \\
\hline Earthworm soil & 15 & 4.9 & 2.8 & 30 & 5.5 & 4.0 & 18 & 2.8 & 1.6 \\
\hline Earthworm/no earthworm ${ }^{\text {b }}$ & 1.3 & 1.5 & 7.1 & 2.4 & 1.5 & 3.4 & 30.3 & 7.3 & 5.9 \\
\hline
\end{tabular}

a Sampling depths are measured in $\mathrm{cm}$.

b Ratio of biphenyl utilizers isolated from earthworm columns to soils without earthworms.

1.2 to 4.4 times more carbon than soils without earthworms. Soil nitrogen content ranged between 0.01 and $1.19 \mathrm{mg}$ $\mathrm{N} \mathrm{g}^{-1}$ soil in the earthworm-treated soil, whereas soils without earthworms ranged between the detection limit of

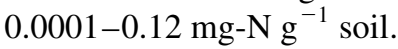

\subsection{Biphenyl-utilizing isolates}

Recovery of Rhodococcus sp. ACS was evaluated to determine the distribution of the inoculum in the bioaugmented soil and its potential for survival in earthworm-treated soils. The inoculum recovery from soils without earthworms approximated $2 \times 10^{7}$ at all depths. Recovery of Rhodococcus sp. ACS in the earthworm-treated soil was below detection $\left(<10^{6} \mathrm{cfu} \mathrm{ml}^{-1}\right)$ at both the $0-2$ and $2-$ $6 \mathrm{~cm}$ depths. However, $1 \times 10^{6} \mathrm{cfu} \mathrm{g}^{-1}$ soil were recovered from the $6-20 \mathrm{~cm}$ depth.

Despite greater inoculum recoveries in soils without earthworms, more biphenyl-utilizing micro-organisms were recovered from earthworm-treated soils as compared to soil without earthworms (Table 4). Biphenyl-utilizers ranged from $1.6 \times 10^{8}$ to $30 \times 10^{8} \mathrm{cfu} \mathrm{g}^{-1}$ soil in earthworm-treated soils, whereas populations in soils without earthworms ranged from $0.27 \times 10^{8}$ to $12 \times 10^{8} \mathrm{cfu} \mathrm{g}^{-1}$ soil. Earthworm-treated soils had between 3.4 and 7.1 times more biphenyl degraders at the 6-20 cm depth than soils without earthworms. Thirty times more biphenyl utilizers were isolated from $0-2 \mathrm{~cm}$ depth in MSM earthwormtreated soils than in soils without earthworms.

\subsection{Gas diffusion}

Methane diffusion coefficients were determined by measuring the methane concentration in the upper and lower air chambers $(H)$ in the soil columns over a period of $340 \mathrm{~min}$. After methane was injected into the lower air reservoir it was detected in the upper air reservoir of the earthworm-treated soil columns after $10 \mathrm{~min}$, while it took $340 \mathrm{~min}$ in the column without earthworms. The experimental gas diffusion coefficients $(D g)$ were $4.45 \times 10^{-3}$ and $5.0 \times 10^{-4} \mathrm{~cm}^{2} \mathrm{~s}^{-1}$ with and without earthworms, respectively, and were obtained by fitting the gas concentration data in the inlet and outlet ends of the columns to the diffusion model's predictions. The model accounted for methane degradation through a first-order reaction characterized by a rate coefficient $(\mu)$. This was simultaneously fitted with the diffusion coefficient to the data. No degradation occurred in the control column, whereas methane depletion in the earthworm-treated soil columns was substantial, requiring a degradation rate coefficient of $\mu=2.5 \times 10^{-4} \mathrm{~s}^{-1}$ to account for the mass removal during the experiment. Fig. 2 shows the model calculation and data for the inlet and for the outlet ends for the earthworm-treated and control columns.

\section{Discussion}

Earthworm activity alleviated the problem of poor aeration through bioturbation and burrowing and was shown to 


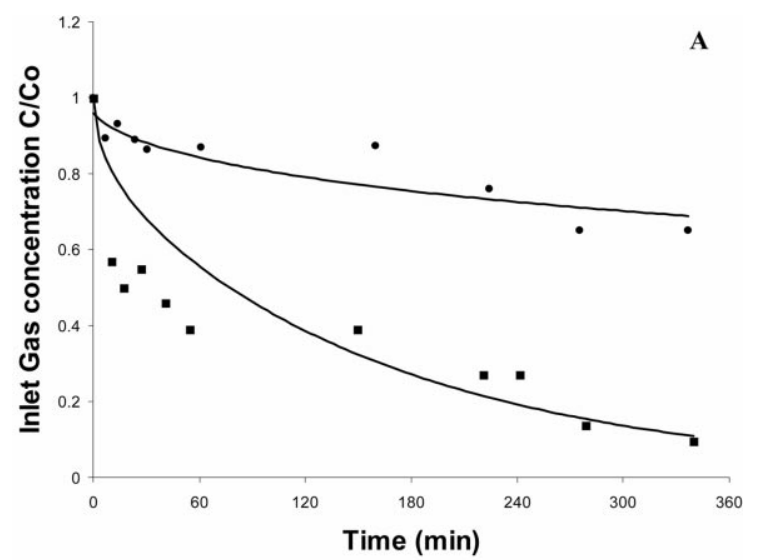

$\mathbf{B}$

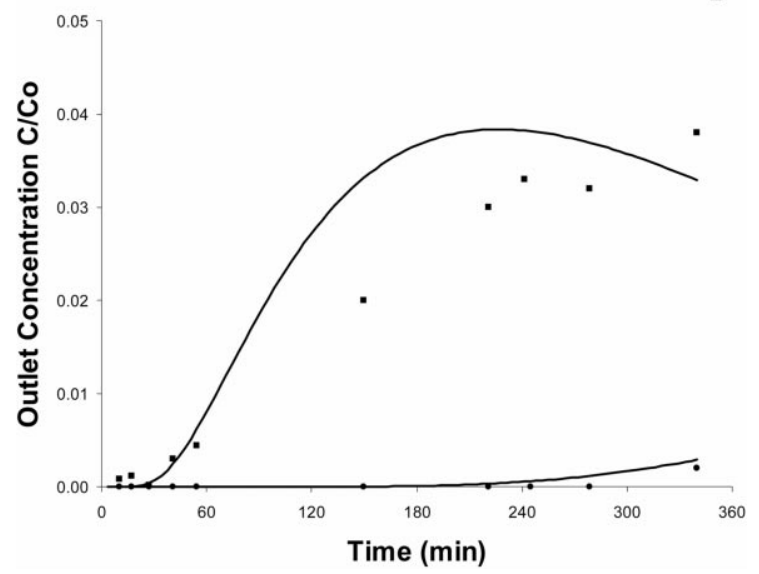

Fig. 2. Predicted (line) and measured (circles) gas concentrations in the inlet end (A) and outlet end (B) in columns. The earthworm-treated soil is the lower set of data points in 2(A) and the upper set of data points in 2(B) whereas the remaining data represents the control columns. Best fit of the model parameters were $D=4.45 \times 10^{-3} \mathrm{~cm}^{2} \mathrm{~s}^{-1}$ and $\mu=2.5 \times 10^{-4} \mathrm{~s}^{-1}$.

modify the biotic and abiotic soil environment in a manner which increased PCB removal. The burrows acted as conduits for the infiltration of inoculum, surfactant, and inducing agents and for the more rapid exchange of gas. In addition, the earthworms deposited nutrient rich casts (Edwards and Bohlen, 1996) that maintained a more metabolically active microbial community (Brown, 1995; Visser, 1985), improving the likelihood of PCB removal.

Soil mesocosms containing $100 \mathrm{mg}$ Aroclor $1242 \mathrm{~kg}^{-1}$ soil were maintained under specific treatment regimes with and without earthworms for 18 weeks after which PCB recoveries by depth were determined. In every case, incorporation of earthworms into contaminated soils significantly increased PCB removal irrespective of the soil amendments. Earthworm activity was greatest within the $2-6 \mathrm{~cm}$ depth, coinciding with the most significant PCB removal as compared to soils without earthworms. Soils without earthworms showed a decrease of $55 \%$ in PCB at the soil surface. A similar decline of $82 \%$ was observed by McDermott et al. (1989) after bioaugmenting PCB contaminated soil without mixing. PCB removal due to volatilization is represented in the PCB recovered from the PUF plug.
The recovered PUF plug PCB represents $0.052 \%$ of the PCB initially added to the soil columns and only $0.52 \%$ of the PCB from the $0-2 \mathrm{~cm}$ depth, the likely source of volatilized PCB. The relatively low recovery of PUF plug PCB suggests volatilization was not a major route of PCB loss in this experiment. Since the columns were not sealed off to the atmosphere on the bottom, unrealistically high oxygen concentrations were maintained in the lowest depths. This resulted in substantially higher PCB removal in the 6$20 \mathrm{~cm}$ depth than would be predicted to occur in a more natural setting. Yet, it reinforces the importance of oxygen as a potentially limiting factor in bioremediation.

Congener recoveries in earthworm tissues suggests $P$. hawayana accumulates PCB in roughly the same congener ratios as the surrounding soil (Table 2). Extraction of PCB from earthworm tissues showed an accumulation of tetraand penta-chlorobiphenyls as compared to an Aroclor 1242 standard. The discrepancy between trichlorobiphenyl recovery in the earthworm tissue and the earthworm-treated soil remains unclear. However, it is suggested that the earthworms consumed organic matter which had adsorbed PCB from the soil. The lower chlorinated congeners were largely degraded, while the more highly chlorinated congeners persisted. Hence repeated consumption of organic matter containing highly chlorinated congeners may have contributed to the accumulation of tetra- and penta- chlorinated congeners in the earthworm tissue.

The inoculum was initially cultured to approximately $10^{8} \mathrm{cfu} \mathrm{ml}^{-1}$. Since $10 \mathrm{ml}$ of the inoculum was added to the soil surface at each amendment $(0-2 \mathrm{~cm}=60 \mathrm{~g}$ soil $)$, the inoculum was effectively $1.7 \times 10^{7} \mathrm{cfu} \mathrm{g}^{-1}$ soil within the $0-2 \mathrm{~cm}$ depth. In soils without earthworms, the inoculum population was approximately $2 \times 10^{7}$ at all depths; whereas, recovery of Rhodococcus sp. ACS in the earthworm-treated soil was below detection $\left(<10^{6} \mathrm{cfu} \mathrm{ml}^{-1}\right)$ at both the $0-2$ and 2-6 cm depths. Interestingly, however, the inoculum was recovered at $1 \times 10^{6} \mathrm{cfu} \mathrm{g}^{-1}$ soil at the 6$20 \mathrm{~cm}$ depth. The improved survival at this depth may be the result of decreased earthworm activity at the lowest depth, thus suggesting a negative correlation between $P$. hawayana activity and Rhodococcus sp. ACS survival. This hypothesis is further supported by the finding that Rhodococcus sp. ACS population decreased by two orders of magnitude after passing through $P$. hawayana in controlled aseptic conditions without soil (data not shown). Although the inoculum cell density in P. hawayana treated soils declined two log units, such a decline is not unusual (Daane et al., 1996). Madsen and Alexander (1982) evaluated the vertical movement of Rhizobium japonicum and $P$. putida added to the surface $2.4 \mathrm{~cm}$ of nonsterile soil. The inoculated soil containing $10^{6} \mathrm{cfu} \mathrm{g}^{-1}$ of $P$. putida, contained only $2.4 \times 10^{2} \mathrm{cfu} \mathrm{g}^{-1}$ soil after transport in Lumbricus rubellus at a depth of $7.3 \mathrm{~cm}$, a 4-log decline. Similarly, only $8 \mathrm{cfu} \mathrm{g}^{-1}$ soil of $R$. japonicum were recovered from the same depth, representing a 6-log decline. Daane et al. (1996) investigated the influence of earthworm 
activity on the transfer of a plasmid from the donor bacterium to indigenous soil micro-organisms. The authors inoculated the top $4 \mathrm{~cm}$ of soil with $10^{8} \mathrm{cfu}^{-1}$ soil of Pseudomonas fluorescens $\mathrm{C} 5 \mathrm{t}$ and recovered $1.38 \times 10^{3} \mathrm{cfu} \mathrm{g}^{-1}$ soil at a depth of $35 \mathrm{~cm}$ after transport by Aporrectodea trapezoides, a 5-log decline in survival. Lumbricus terrestris treated soil amended with $10^{8}$ cfu of $P$. fluorescens $\mathrm{C} 5 \mathrm{t} \mathrm{g}^{-1}$ soil resulted in recovery of $2.12 \times 10^{2} \mathrm{cfu} \mathrm{g}^{-1}$ soil at a depth of $35 \mathrm{~cm}$, a 6-log decline in recovery. Transport of the same bacterium by L. rubellus resulted in the recovery of $1.58 \times 10^{2} \mathrm{cfu} \mathrm{g}^{-1}$ soil at a depth of $20 \mathrm{~cm}$, a 6-log decline.

Bacterial transport in the soil matrix is a function of several variables including bacterial size and surface hydrophobicity, soil structure, pore-size distribution, soil organic matter, clay, and water content, and macrofauna activity (Devare and Alexander, 1995; Gammack et al., 1992; Lindqvist and Enfield, 1992). In an earthworm-influenced system, additional variables such as gut passage (Kristufec et al., 1992; Tiwari and Mishra, 1993), external tissue transport (Thornton, 1970), and type and amount of organic matter available in the soil (Stephens et al., 1995) will also greatly influence the survival and transport of the micro-organism. Contrary to expectations, inoculum penetration into the $6-20 \mathrm{~cm}$ depth was not dependent on the presence of earthworms. Observed inoculum transport in soils without earthworms may have been fortuitously enhanced by the use of a coarse loamy soil, and employment of a surfactant. It is also possible that inoculum transport was enhanced early in the experiment due to insufficient packing of the column, providing anomalously large macropores in the mesocosms. Although the inoculum was found at all depths in soils without earthworms, interestingly, it did not result in higher PCB degradation. This result begs the question, is the PCB-degrading inoculum necessary for PCB degradation in soils treated with earthworms?

As the literature suggests (Edwards and Bohlen, 1996; Lee, 1985), incorporation of earthworms increased soil aeration as measured by the higher gas diffusion coefficient, which increased by an order of magnitude in earthwormtreated soils as compared to soils without earthworms. The increased oxygen diffusion made it possible for earthwormtreated soils to sustain more numerous populations of aerobic micro-organisms, a fraction of which may have contributed to PCB removal. However, these results are contrary to K. P. Barley (1958), who suggested the total cross-sectional area of Allolobophora caliginosa tunnels in the subsoil of a 10-year-old pasture were too small to make a useful contribution to gas exchange by diffusion. Based on the total cross sectional area and frequency distribution of earthworm tunnels, a maximum contribution of the tunnels to the coefficient of gaseous diffusion was calculated to be $5 \times 10^{-4} D_{0}$ at $20 \mathrm{~cm}$ depth and $7 \times 10^{-5} D_{0}$ at $50 \mathrm{~cm}$ depth, where $D_{0}$ is the coefficient of diffusion in air (Barley, 1958). The predicted contribution of earthworm tunnels to gas diffusion was markedly lower in Barley (1958) than in the presented work. This may best be explained by the fact that the earth- worm population density in this study was approximately an order of magnitude higher than the typical pasture population density of 500 earthworms $\mathrm{m}^{-2}$. Additionally, the coarse loamy texture of this study's soil may have afforded a higher basal gas diffusion rate than the soil used in Barley (1958). Although such high earthworm populations are unrealistic for a pasture setting, it is easily maintained in a controlled environment where conditions are conducive for earthworm propagation and food is plentiful. PCB contaminated soil is routinely excavated from the contaminated site and stored in drums for disposal in landfills or incinerators. These drums provide optimal parameters for manipulating the soil environment, enabling otherwise unrealistic earthworm populations to thrive, thereby hastening the remediation process.

It is particularly interesting to note the introduction of a decay constant for methane into the diffusion model for the earthworm-treated soils. The need for a decay constant suggests methane utilization by indigenous micro-organisms. Since a decay constant was a unique feature of soils with earthworms, it suggests earthworms may have modified the indigenous soil microbial community, enriching the soil with micro-organisms competent in methane transformation (methanotrophs). Yet, methanotrophs are typically associated with methanogens, a population that is active under anaerobic conditions. Although it is possible that the limited diffusion within soil aggregates or casts in combination with metabolically active microflora may have led to anaerobic microsites conducive for methanogenic activity, it does not explain why soils without earthworms, having an even lower diffusion coefficient, did not develop similar methane-producing and transforming microbial populations. An intriguing hypothesis for why earthworm-treated soils depleted methane may lie in the ecological interaction between the earthworms and the indigenous micro-organisms.

The earthworms enriched for greater populations of metabolically active micro-organisms by introducing nutrientrich casts and excretions into the soil in the form of mucoproteins, ammonia, urea, and uric acid and allantoin from urine (Edwards and Bohlen, 1996). This is supported by the increased recovery of biphenyl-utilizing micro-organisms and higher soil nitrogen content in earthworm-treated soils. These reduced nitrogen-containing compounds would characteristically develop an active ammonia-oxidizing community. Ammonia oxidizers are chemoautotrophs, in the family Nitrobacteraceae, and are capable of oxidizing ammonium, providing energy for the fixation of carbon dioxide (Bedard and Knowles, 1989). It has previously been shown that ammonia-oxidizing bacteria can oxidize methane (Jones and Morita, 1983), although they cannot use the energy from the reaction for growth (Bedard and Knowles, 1989). Thus, methane transformation in soils with earthworms may best be interpreted as evidence for the presence of an active ammonia-oxidizing microbial community. It has been suggested that methane mono-oxygenase 
and ammonia mono-oxygenase are evolutionarily related enzymes, and oxidize many of the same compounds (Holmes et al., 1995). Consequently, an active ammoniaoxidizer population may be capable of depleting the methane tracer over the course of the $340 \mathrm{~min}$ diffusion experiment. Moreover, researchers have shown that both methane and ammonia mono-oxygenases are effective in oxidizing recalcitrant xenobiotic pollutants such as TCE (Moran and Hickey, 1997; Palumbo et al., 1991) and PCB (Linder and Adriaens, 1996). Thus, the incorporation of earthworms into PCB-contaminated soil may have fortuitously enriched for an active ammonia-oxidizer population capable of PCB transformation. The proposed effect of earthworms on enhanced methane consumption has relevance to global environmental change and is the subject of further study in our laboratory.

\section{Conclusions}

Bioremediation of PCB-contaminated soil is constrained by a number of factors including, PCB bioavailability, the requirement for an effective non-toxic $\mathrm{PCB}$ inducing compound, and the lack of micro-organisms with broad specificity PCB degrading enzymes. Other problems associated with bioaugmentation include maintaining metabolic activity of the inoculum after application, subsurface dispersal of the PCB-degrading inoculum, and maintaining suitable aerobic PCB-degrading conditions within the soil profile. This study demonstrated an integrated approach that addresses each of these issues. Sorbitan trioleate enabled greater PCB bioavailability, while the non-toxic compounds carvone and salicylic acid induced for PCB degrading enzymes in the inoculum. Two PCB-degrading isolates were utilized providing a more diverse array of PCB-degrading enzymes than a single bacterium. Twiceweekly applications of the inoculum continually replenished the degrader bacteria at high population densities, lessening concerns over the inoculum's survival and activity in the soil. Burrowing and bioturbation by earthworms enabled hands-off mixing of the soil, relieving the need to till or manually mix in the inoculum. It is suggested that the earthworm-mediated soil mixing and improved aeration was responsible for achieving 65\% PCB degradation at subsurface depths, as compared to $10 \%$ achieved in prior studies without manual mixing (McDermott et al., 1989). The use of an anecic species of earthworm enabled the formation of burrows that provided 10-fold greater gas diffusion through the soil than in soils without earthworms. Although PCB removal was enhanced by bioaugmentation, the considerable success of biostimulated and minimal salts-amended soils in earthworm-treated columns along with evidence for methane degradation, suggests earthworms may indirectly contribute to PCB degradation through an enrichment of an ammonia-oxidizing, PCB-cometabolizing microbial community.

\section{Acknowledgements}

We thank Dr Marc DeShusses for providing valuable assistance in conducting the methane diffusion assay, Peggy Resketo for her technical assistance with the gas chromatography, Dr Joann Whalen for her assistance in confirming the identification of Pheretima hawayana, and Katechan Jampachaisri for her invaluable help with the statistical analyses.

\section{References}

Alexander, M., 1999. Biodegradation and Bioremediation. Academic Press, San Diego.

Barley, K.P., 1958. Earthworms and soi fertility. IV. The influence of earthworms on the physical properties of a red-brown earth. Australian Journal of Agricultural Research 10, 371-377.

Barriault, D., Sylvestre, M., 1993. Factors affecting PCB degradation by an implanted bacterial strain in soil microcosms. Canadian Journal of Microbiology 39, 594-602.

Bedard, C., Knowles, R., 1989. Physiology, biochemistry, and specific inhibitors of $\mathrm{CH} 4, \mathrm{NH} 4+$, and $\mathrm{CO}$ oxidation by methanotrophs and nitrifiers. Microbiological Reviews 53, 68-84.

Bedard, D.L., Brennan, M.J., Unterman, R., 1983. Bacterial degradation of PCBs: Evidence of distinct pathways in Corynebacterium sp. MB1 and Alcaligenes eutrophus H850. In: Proceedings of the 1983 PCB Seminar Electrical Power Research Institute, Palo Alto, California, pp. 4:101117.

Bouche, M.B., 1975. Action de la faune sur les etats de la matiere organique dans les ecosystemes. In: Kilbertus, K., Reisinger, O., Mourey, A., Fonsea, J.A.C.D. (Eds.). Biodegradation et Humification. Sarruguemines, Pierron, pp. 157-168.

Bouma, J., Belmans, C.F.M., Dekker, L.W., 1982. Water infiltration and redistribution in a silt loam soil with vertical worm channels. Journal of Soil Science Society of America 46, 917-921.

Brown, G.G., 1995. How do earthworms affect microfloral and faunal community diversity? Plant and Soil 170, 209-231.

Brunner, W., Sutherland, F.H., Focht, D.D., 1985. Enhanced biodegradation of polychlorinated biphenyls in soil by analogue enrichment and bacterial inoculation. Journal of Environmental Quality 14, 324-328.

Carslaw, H.S., Jaeger, J.C., 1959. Conduction of Heat in Solids. Clarendon Press, Oxford

Daane, L.L., Molina, J.A.E., Berry, E.C., Sadowsky, M.J., 1996. Influence of earthworm activity on gene transfer from Pseudomonas fluorescens to indigenous soil bacteria. Applied and Environmental Microbiology $62,515-521$.

Daane, L.L., Molina, J.A.E., Sadowsky, M.J., 1997. Plasmid transfer between spatially separated donor and recipient bacteria in earthworm-containing soil microcosms. Applied and Environmental Microbiology 63, 679-686.

Devare, M., Alexander, M., 1995. Bacterial transport and phenanthrene biodegradation in soil and aquifer sand. Journal of the Soil Science Society of America 59, 1316-1320.

Doube, B.M., Ryder, M.H., Davoren, C.W., Stephens, P.M., 1994. Enhanced root nodulation of subterranean clover (Trifolium subterraneum) by Rhizobium leguminosarium biovar. trifolii in the presence of the earthworm Aporrectodea trapezoides (Lumbricidae). Biology and Fertility of Soils 18, 169-174.

Edwards, C.A., Bohlen, P.J., 1996. Biology and Ecology of Earthworms. Chapman \& Hall, New York.

Edwards, W.M., Shipitalo, M.J., Traina, S.J., Edwards, C.A., Owens, L.B., 1992. Role of Lumbricus terrestris (L.) burrows on quality of infiltrating water. Soil Biology and Biochemistry 24, 1555-1561. 
Ehlers, W., 1975. Observations on the earthworm channels and infiltration on tilled and untilled loess soil. Soil Science 119, 242-249.

Elsas, J.D.v., Heijnen, C.E., 1990. Methods for the introduction of bacteria into soil: a review. Biology and Fertility of Soils 10, 127-133.

Erickson, M.D., 1997. Analytical Chemistry of PCBs. Lewis Publishers, Boca Raton.

Farenhorst, A., Topp, E., Bowman, B.T., Tomlin, A.D., 2000. Earthworm burrowing and feeding activity and the potential for atrazine transport by preferential flow. Soil Biology and Biochemistry 32, 479-488.

Furukawa, K., 1982. Microbial degradation of polychlorinated biphenyls (PCBs). In: Chakrabarty, A.M. (Ed.). Biodegradation and Detoxification of Environmental Pollutants. CRC Press, Inc, Florida, pp. 33-57.

Gammack, S.M., Paterson, E., Kemp, J.S., Cresser, M.S., Killham, K., 1992. Factors affecting movement of microorganisms in soils. In: Strotzky, G., Bolla, L.M. (Eds.). Soil Biochemistry, vol. 7. Marcel Dekker Inc, New York, pp. 263-305.

Gilbert, E.S., Crowley, D.E., 1997. Plant compounds that induce polychlorinated biphenyl biodegradation by Arthrobacter sp. strain B1B. Applied and Environmental Microbiology 63, 1933-1938.

Gilbert, E.S., Crowley, D.E., 1998. Repeated application of carvoneinduced bacteria to enhance biodegradation of polychlorinated biphenyls in soil. Applied Microbiology and Biotechnology 50, 489-494.

Goldstein, R.M., Mallory, L.M., Alexander, M., 1985. Reasons for possible failure of inoculation to enhance biodegradation. Applied and Environmental Microbiology 50, 977-983.

Haluska, L., Barancikova, G., Balaz, S., Dercova, K., Vrana, B., Paz-Weisshaar, M., Furciova, E., Bielek, P., 1995. Degradation of PCB in different soils by inoculated Alcaligenes xylosoxidans. Sci. of the Total Env. $175,275-285$.

Hampson, M.C., Coombes, J.W., 1989. Pathogenesis of Synchytrium endobioticum. VII. Earthworms as vectors of wart disease of potato. Plant and Soil 116, 147-150.

Harding, G.L., 1997. Bioremediation and the dissimilatory reduction of metals. In: Hurst, C.J., Kudsen, G.R., McInerney, M.J., Stetzenbach, L.D., Walter, M.V. (Eds.). Manual of Environmental Microbiology. ASM Press, Washington, DC, pp. 806-810.

Harkness, M.R., McDermott, J.B., Abramowicz, D.A., Salvo, J.J., Flanagan, W.P., Stephens, M.L., Mondello, F.J., May, R.J., Lobos, J.H., Carroll, K.M., Brennan, M.J., Bracco, A.A., Fish, K.M., Warner, G.L., Wilson, P.R., Dietrich, D.K., Lin, D.T., Morgan, D.B., Gately, W.L., 1993. In situ stimulation of aerobic PCB biodegradation in Hudson River sediments. Science 259, 503-507.

Holmes, A.J., Costello, A., Lidstrom, M.E., Murrell, J.C., 1995. Evidence that particulate methane monooxygenase and ammonia monooxygenase may be evolutionarily related. FEMS Microbiology Letters 132, 203208.

Hutchinson, S.A., Kamel, M., 1956. The effect of earthworms on the dispersal of soil fungi. Journal of the Soil Science Society of America 7, 213218.

Jones, R.D., Morita, R.Y., 1983. Methane oxidation by nitrosococcus oceanus and Nitrosomonas europaea. Applied and Environmental Microbiology 45, 401-410.

Jury, W.A., Roth, K., 1990. Transfer Functions and Solute Movement Through Soil. Birkhaeuser, Basel, Switzerland.

Kohler, H.P.E., Kohler-Staub, D., Focht, D.D., 1988. Cometabolism of polychlorinated biphenyls: Enhanced transformation of Aroclor 1254 by growing bacterial cells. Applied and Environmental Microbiology 54, 1940-1945.

Kretzschmar, A., 1978. Quantification ecologique des galeries de lombriciens. Techniques et premieres estimations. Pedobiologia 18, 31-38.

Kretzschmar, A., 1987. Soil partitioning effect of an earthworm burrow system. Biology and Fertility of Soils 3, 121-124.

Kristufec, V., Ravasz, K., Pizl, V., 1992. Changes in densities of bacteria and microfungi during gut transit in Lumbricus rubellus and Aporrectodea caliginosa (Oligochaeta: Lumbricidae). Soil Biology and Biochemistry 24, 1499-1500.
Lajoie, C.A., Layton, A.C., Sayler, G.S., 1994. Cometabolic oxidation of polychlorinated biphenyls in soil with a surfactant-based field application vector. Applied and Environmental Microbiology 60, 2826-2833.

Lajoie, C.A., Zylstra, G.J., DeFlaun, M.F., Strom, P.F., 1993. Development of field application vectors for bioremediation of soils contaminated with polychlorinated biphenyls. Applied and Environmental Microbiology $59,1735-1741$.

Lee, K.E., 1985. Earthworms, Their Ecology and Relationships with Soils and Land Use. Academic Press, Sydney.

Linder, A.S., Adriaens, P., 1996. Microbial ecology of PCB transformation in the environment: a niche for methanotrophs?. In: Lidstrom, M.E., Tabita, F.R. (Eds.). Microbial Growth on C1 Compounds. Kluwer Academic Publishers, Netherlands, pp. 269-276.

Lindqvist, R., Enfield, C.G., 1992. Cell density and non-equilibrium sorption effects on bacterial dispersal in groundwater microcosms. Microbial Ecology 24, 25-41.

Madsen, E.L., Alexander, M., 1982. Transport of Rhizobium and Pseudomonas through soil. Journal of the Soil Science Society of America 46, 557-560.

Margesin, R., Zimmerbauer, A., Schinner, F., 2000. Monitoring of bioremediation by soil biological activities. Chemosphere 40, 339-346.

McDermott, J.B., Unterman, R., Brennan, M.J., Brooks, R.E., Bobley, D.P., Schwartz, C.C., Dietrich, D.K., 1989. Two strategies for PCB soil remediation: biodegradation and surfactant extraction. Environmental Progress 8, 46-51.

Moran, B.N., Hickey, W.J., 1997. Trichloroethylene biodegradation by mesophilic and psychrophilic ammonia oxidizers and methanotrophs in groundwater microcosms. Applied and Environmental Microbiology 63, 3866-3871

Palumbo, A.V., Eng, W., Strandberg, G.W., 1991. The effects of groundwater chemistry on cometabolism of chlorinated solvents by methanotrophic bacteria. In: Baker, R.A. (Ed.). Organic Substances and Sediments in Water, vol. 3. Lewis Publishers, Inc, Chelsea Michigan, pp. 225-238.

Pivetz, B.E., Steenhuis, T.S., 1995. Soil matrix and macropore biodegradation of 2,4-D. Journal of Environmental Quality 24, 564-570.

Robinson, G.K., Lenn, M.J., 1994. The bioremediation of polychlorinated biphenyls (PCBs): problems and perspectives. Biotechnology and Genetic Engineering Reviews 12, 139-188.

Rowell, D.L., 1994. Soil Science: Methods and Applications. Longman Group UK Limited, Essex.

Schack-Kirchner, H., Hildebrand, E.E., 1998. Changes in soil structure and aeration due to liming and acid irrigation. Plant and Soil 199, 167-176.

Schulz, D.E., Petrick, G., Duinker, J.C., 1989. Complete characterization of polychlorinated biphenyl congeners in commercial Aroclor and Clophen mixtures by multidimensional gas chromatography-electron capture detection. Environmental Science and Technology 23, 852-859.

Singer, A.C., Crowley, D.E., Menge, J.A., 1999. Anecic earthworms as a means for delivery of biocontrol agents and antagonism towards Phytophthora cinnamomi. Pedobiologia 43, 771-775.

Singer, A.C., Gilbert, E.S., Luepromchai, E., Crowley, D.E., 2000. Bioremediation of polychlorinated biphenyl-contaminated soil using carvone and surfactant-grown bacteria. Applied Microbiology and Biochemistry 54, 838-843.

Stephens, P.M., Davoren, C.W., Hawke, B.G., 1995. Influence of barley straw and the lumbricid earthworm Aporrectodea trapezoides on Rhizobium meliloti L5-30R, Pseudomonas corrugata 2140R, microbial biomass and microbial activity in a red-brown earth soil. Soil Biology and Biochemistry 27, 1489-1497.

Stephens, P.M., Davoren, C.W., Ryder, M.H., Doube, B.M., 1994. Influence of the earthworm Aporrectodea trapezoides (Lumbricidae) on the colonization of alfalfa (Medicago sativa $\mathrm{L}$.) roots by Rhizobium meliloti L5-30R and the survival of $R$. meliloti L5-30R in soil. Biology and Fertility of Soils 18, 63-70.

Thornton, M.L., 1970. Transport of soil-dwelling aquatic phycomycetes by earthworms. Transactions of the British Mycology Society 55, 391-397.

Thorpe, I.S., Prosser, J.I., Glover, L.A., Killham, K., 1996. The role of the 
earthworm Lumbricus terrestris in the transport of bacterial inocula through soil. Biology and Fertility of Soils 23, 132-139.

Tiwari, S.C., Mishra, R.R., 1993. Fungal abundance and diversity in earthworm casts and in uningested soil. Biology and Fertility of Soils 16, $131-134$.

Viney, I., Bewley, R.J.F., 1990. Preliminary studies on the development of a microbiological treatment for polychlorinated biphenyls. Archives in Environmental Contamination and Toxicology 19, 789-796.
Visser, S., 1985. Role of the soil invertebrates in determining the composition of soil microbial communities. In: Fitter, A., Atkinson, D., Read, D.J., Usher, M.B. (Eds.). Ecological Interactions in Soil. Blackwell Scientific, Oxford, pp. 297-318.

Wiegel, J., Wu, Q., 2000. Microbial reductive dehalogenation of polychlorinated biphenyls. FEMS Microbial Ecology 32, 1-15.

Wolters, V., 2000. Invertebrate control of soil organic matter stability. Biology and Fertility of Soils 31, 1-19. 